Asian J. Med. Biol. Res. 2020, 6 (2), 212-221; doi: 10.3329/ajmbr.v6i2.48052

\author{
Asian Journal of \\ Medical and Biological Research \\ ISSN 2411-4472 (Print) 2412-5571 (Online) \\ www.ebupress.com/journal/ajmbr
}

\title{
Article \\ Incidence of reproductive disorders of goat in Dinajpur district of Bangladesh
}

\author{
Umme Kulsum ${ }^{1}$, Mst. Sogra Banu Juli ${ }^{1}$, Begum Fatema Zohara ${ }^{1}$, Md. Nurnoby Islam ${ }^{1}$ and Mahfuza Akther ${ }^{2}$ \\ ${ }^{1}$ Department of Medicine, Surgery and Obstetrics, Hajee Mohammad Danesh Science and Technology \\ University, Dinajpur, Bangladesh \\ ${ }^{2}$ Department of Pathology and Parasitology, Hajee Mohammad Danesh Science and Technology University, \\ Dinajpur, Bangladesh
}

*Corresponding author: Mst. Sogra Banu Juli, Department of Medicine, Surgery and Obstetrics, Hajee Mohammad Danesh Science and Technology University, Dinajpur, Bangladesh. Phone: +8801729519747; Email: julivetmed@gmail.com

Received: 30 April 2020/Accepted: 23 June 2020/ Published: 30 June 2020

\begin{abstract}
The study was conducted at Upazila Livestock Office, Sadar, Dinajpur of Bangladesh from January 2018 to December 2018 to investigate the incidence of reproductive disorders in goat. Data on reproductive disorders were collected on the basis of owner's complain and observed clinical signs. Age and season wise occurrences of reproductive disorders were also recorded. Descriptive statistical analysis was done. Out of 2484 clinical cases, a total of 107 reproductive disorders of goat were recorded. Incidence of abortion (38.3\%) was higher and pyometra $(0.9 \%)$ was lower among reproductive disorder in goat. The incidence of reproductive disorders of goat was higher in group-2 (above 1-2 years) (36.4\%) followed by group-1 (upto 1 year) (21.6\%), group-3 (above 23 years) (21.5\%), group-5 (above 4 years) (15.3\%) and group-4 (above 3-4 years) (3.6\%). Among reproductive disorders, the incidence of abortion was higher in group-2 (58.9\%) followed by retained placenta $(50 \%)$ in group-4, metritis $(47 \%)$ and dystocia $(23.5 \%)$ in group-5, repeat breeding $(17.4 \%)$ and anestrus $(4.3 \%)$ in group-3, and pyometra (2.5\%) in group-2. Slight seasonal variation among individual case of reproductive disorders were recorded, highest in winter $(34.5 \%)$ than summer $(32.4 \%)$ and rainy season $(31.7 \%)$. The incidence rate of abortion was high in each season (summer 25\%, rainy $32.3 \%$ and winter $56.7 \%$ ). In case of retained placenta and dystocia, the incidence was high in summer season (22.2\%). But in case of metritis and repeat breeding, the incidence was high in rainy season (32.3\% and $14.7 \%$ respectively). For treatment of reproductive disorders in goat, antibiotics drugs (35\%) were used most commonly and hormonal drugs (3\%) used in lower percentages. It was concluded that the most pressing constraint on goat reproduction in Bangladesh is abortion, retained placenta, dystocia and metritis. Strategies should be taken to minimize their occurrence.
\end{abstract}

Keywords: abortion; age; goat; reproductive disorders; season

\section{Introduction}

Livestock is the most prospective sector which addresses the problems of landless, marginal and small-scale farmers and capable of helping in poverty alleviation (Moyo and Swanepoel, 2010). According to Livestock Economic Section (DLS) the contribution of the livestock sector to GDP was 3.40\% in 2017-2018. According to the report of Livestock Economic Section (DLS), the population of total ruminant raised to 551.39 lakh, sheep 34.68lakh and goat 261.00 lakh in the final year 2017-2018. In the livestock sector, small ruminants especially goat and sheep are plays very important role in rural economy and nutrition. Goat is numerically and economically important and promising animal resources in the developing countries especially in Asia and Africa (Hussain, 1999). Goats rank first position in terms of total livestock population in Bangladesh (FAO, 1999). The goat is called the "Poor man"s cow" is the second important livestock in Bangladesh which plays an 
important role in the rural economy and earn substantial amount of foreign currency by exporting skin and others by products (Kamaruddin, 2003). The importance of goat is strongly emphasized for their versatile production profile and valuable contribution like meat, milk, industrial raw product such as skin, fiber and manure.

Among all goats (90\%) reared are Black Bengal (Amin et al., 2001), reputed for their prolificacy, fertility, early sexual maturity, adaptability to hot humid conditions and superior quality meat and skin (Devendra and Burns, 1983; Hussain, 1999; Amin et al., 2001). Relatively low birth weight, slow growth rate and insufficient milk produced by does, were identified as the major constraints directly associated with higher kid mortality and this is responsible for reduction of the total productivity (Hussain, 1993). Reproductive disorders of goat and sheep are the significant economic problems. The reproductive disorders are the major causes of reduced fertility in goat and sheep. Reproductive abnormalities have been described as the largest single cause of loss of livestock production (McDowell, 1972). It has negative impact on meat production since pregnancy and parturition are prerequisite for reproduction. Reproduction of goats has an effect on successful fertility (Sattar and Khan, 1988). Gynaeco-obstetrical disorders like dystocia, abortion, retention of placenta and other miscellaneous abnormalities like metritis, pyometra, vaginitis are the vital factors causing economical loss to goat and sheep industry. However, in maximum cases treatment cost of reproductive disorders is high. For this reason, farmers lose their interest to rear goat and sheep. It is important to diagnose the reproductive disorders properly for the improvement of reproductive and productive efficiency. The total number of goats was 910418, respectively in, Dinajpur district (DLS, 2017). However, there is no baseline study on the reproductive disorders and their management in Dinajpur district. Therefore, the study was designed for determine the incidence of major reproductive disorders, causal factors along with different therapeutic drugs used in goats.

\section{Materials and Methods}

The study was conducted at Upazila Livestock Office, Dinajpur Sadar, Dinajpur under the supervision of Department of Medicine, Surgery and Obstetrics. The study was conducted for a period of one year from January, 2018 to December, 2018. All the sick animals brought for treatment to the Upazila Livestock Office were used for this study. The total number of clinical cases of goats were 2484 among them the reproductive disorders of goats were 107. In order to investigate the incidence of reproductive disorders in goat, a total number of 107 goats were examined on the basis of owner's complaint and observed clinical findings. The influence of the age of goat, and seasonal variation on the incidence of diseases was studied by dividing the infected goat into five age groups (Group-1 up to 1 year, Group-2 above 1 to 2 years, Group-3 above 2 to 3 years, Group- 4 above 3 to 4 years, Group- 5 (above 4 years) and also seasonal variation by dividing Season-1 (March-June) summer season and Season-2 (July-October) rainy season and Season-3 (November-February) winter season. For collection of data, direct interview of owner attended to the Upazila Livestock Office, Dinajpur Sadar, Dinajpur daily from 9.00 am to 4.00 pm by using questionnaire method was used. Information given by the owners was recorded on questionnaire. The questionnaire was prepared considering to the objectives of the study, and was designed in such a way that the farmers can understand easily. After taking history from owner individual goat was examined and diagnosed the reproductive disorders. Body condition score (BCS), behavior, posture, gait, superficial skin, salivation, nasal discharge, locomotive disturbance was observed by distant visual examination of the patients. Examination of different external parts of the body of each animal were done clinically brought at Upazila Livestock Office by using various close observation techniques. The animals were clinically examined at veterinary hospital and temperature, pulse and respiratory rate from each of the animal were recorded. The presented clinical manifestations of various goat were recorded and the farmer's complaint in relation to the disease were recorded carefully. Clinical Findings from each of the animal were observed and recorded. The reproductive disorders were diagnosed by clinical findings, physical examination and history of disease. Disease incidence was calculated by using following formula:

$$
\text { Incidence }(\%)=\frac{\text { No. of affected goat with reproductive disorders }}{\text { Total clinical cases in goat }} \times 100
$$

The data were recorded and analyzed statistically by using software "SPSS" (version 17). One-way ANOVA were performed and the results were expressed in percentage with $\mathrm{P}$ value and significance was determined $(\mathrm{P}<0.05)$. 


\section{Results and Discussion}

The incidence of reproductive disorders are shown in Table 1. The major reproductive disorders in female goats were recorded abortion (38.3\%), metritis $(23.4 \%)$, dystocia (15.8\%), retained placenta (10.3\%), repeat breeding $(9.3 \%)$, anestrus $(1.8 \%)$, and pyometra $(0.9 \%)$. The highest incidence of reproductive disorders was recorded in abortion $(38.3 \%)$ and lowest incidence was recorded in case of pyometra (0.9\%) (Table 1). This finding (abortion) is slightly lower than that of Ahmed et al. (2008) who reported 43.7\% incidence of abortion and higher than the result of Durrani and Kamal (2009) who reported 23\% abortion in goat in Lahore, Pakistan. On the other hand, Ahammad et al. (2015) reported 22\% abortion in goat in Mymensingh district, Bangladesh. Wosu and Anene (1990) stated that the incidence of abortion was $17.2 \%$ and $12.3 \%$ in goats. The incidence of retained placenta was $10.3 \%$ in goats in the present study. This result is similar with Ahammad et al. (2015) who reported $12 \%$ retained placenta in goat and very lower than Red Sokoto goats (95.7\%). In comparison, (Rahman et al., 1977) and (Fthenaki et al., 2000) stated that the incidence of retained placenta was (2.2\%) and $(1.5 \%)$ of goat. Incidence of retained placenta was highest in cattle $(61.9 \%)$ followed by goats (34.0\%). Zahraddeen et al. (2010) reported $34.0 \%$ retained placenta in goat that is higher than the present study. The incidence rate of dystocia was $15.8 \%$ in goats in the present study, which is slightly lower (20.7\%) than Zahraddeen et al. (2010). In another study, that was observed by Srivastava et al. (1985) who reported occurrence of dystocia 3.2\% in local goat but lower than Ahammad et al. (2015) who reported $41 \%$ dystocia in goats. Incidence of dystocia in goat had been reported to be about 7\% (Abdul-Rahman et al., 2000) and the fetal causes of dystocia were $44.44 \%$ (Anusha et al., 2016). Phillip et al. (1985) reported fetal oversize in $9.4 \%$ of goats requiring caesarean section to relieve dystocia. In another study, Majeed and Taha (1989) reported 52.9\% fetal and $47.1 \%$ maternal dystocia but $8.57 \%$ of the dystocia in both maternal and fetal causes. Wosu and Anene (1990) observed $49.5 \%$ dystocia in goat that is higher than the present study. Among reproductive disorders, the incidence of pyometra was $0.9 \%$ in goats in present study. This result is slightly lower than that of Ahmed (1993) who reported 1.4\% occurrence of pyometra in goat and lower than the finding of Ahammad et al. (2015) who reported 3\% pyometra in goat. Higher percentage of pyometra was recorded by who have observed $81.8 \%$ pyometra in Red Sokoto goats. This disorder was recorded in $1.8 \%$ in goat in the present study. This result is slightly lower than that of Durrani and Kamal (2009) who reported 2.3\% anoestrus in goat in Lahore, Pakistan. The incidence of metritis was $23.4 \%$ in the present study. This study is higher than that Zenebe et al. (2015) who reported $3(5.56 \%)$ in ruminants (cattle, sheep and goat). There was significant difference in the incidence of abortion and metritis in goat in relation to age. But in case of retained placenta, dystocia, pyometra, anestrus and repeat breeding, there was no significant difference. In the Table 2, group-2 was larger population than other groups. In goat, among different reproductive disorders, the incidence was higher in abortion and lower in pyometra. In case of abortion, highest incidence (58.9\%) was recorded above 1-2 years and lowest incidence (54.8\%) was recorded above 4 years. Incidence of retained placenta was found 50\% in group-4 but in group-2 (11.9\%), group-5 $(11.7 \%)$, and lowest in group-1 (4.1\%) and group-3 (4.1\%) respectively. Metritis was higher $(47 \%)$ in group-5 (above 4 years) and lower (7.6\%) in group-2 (above 1-2 years). Animals above 4 years had high incidence of dystocia (23.5\%) and in case of group-3 (above 2-3 years), group-1 (upto1 year) and group-2 (above 1-2 years), the incidence was recorded $21.7 \%, 12.5 \%$ and $12.8 \%$ respectively. The incidence rate of pyometra was $0 \%$ in all groups except group-2 $(2.5 \%)$ that means above 1-2 years. In case of anestrus, the incidence rate was highest in group-3 (4.3\%) and lowest in group-2 $(2.5 \%)$. Repeat breeding was highest (16.6\%) in group-1 (upto1 year) and group-3 (16.6\%) than other groups. Overall incidence of reproductive disorders was highest (36.4\%) in group-2 (above 1-2 years) followed by group-1 (21.6\%), group-3 (21.5\%), group-5 (15.3\%) and group-4 (3.6\%) (Table 2). The highest incidence of overall reproductive disorders in goat on the basis of age was recorded (36.4\%) in group-2 (above 1-2 years) in which highest incidence was observed in abortion (58.9\%). This result is similar with Zahraddeen et al. (2010) who observed that the young animals were more prone to abortion then followed by adults, and the old having the lowest incidence. The dystocia was highest (23.5\%) in group-5 (above 4 years) in present study. But Hussain et al. (2010) reported that young goats 
(1-2.5 years old) were more prone to dystocia, as similarly reported by Zahraddeen (2010). Majeed and Taha (1989) reported that incidence of dystocia was higher in two-year-old does and at first kidding. In another study, Islam et al. (2015) who reported that the incidence of dystocia was recorded $4.5 \%$ in young, $1.1 \%$ in adult and $2.3 \%$ in older respectively in small ruminant. In case of retained placenta, the highest incidence (50\%) was recorded in group-4 (above 3-4 years). This result is similar with Zahraddeen et al. (2010) who observed that retained placenta was more common in adults than in young and old animals. In another study, Islam et al. (2015) reported that the incidence of retained placenta was recorded 5.7\% in young, $2.3 \%$ in adult and $2.3 \%$ in older respectively in small ruminant. The incidence of metritis was higher $47 \%$ in group- 5 (above 4 years) in the present study. Ali et al. (2011) reported that metritis was higher in A2 (2-5 year) age group. In case of anestrus, the highest value was recorded $4.3 \%$ in group-3 (above 2-3 years) and $2.5 \%$ in group-2 (above 1-2 years) in the present study. Zenebe et al. (2015) who observed $20.4 \%, 7.9 \%$ and $4.5 \%$ anoestrus in young, adult and old ages respectively. In another study, Islam et al. (2015) reported that the incidence of anestrus was recorded $20.4 \%$ in young, $7.9 \%$ in adult and $4.5 \%$ in older respectively in small ruminant. The incidence of repeat breeding was recorded (17.4\%) in group-3 (above 2-3 years), (16.6\%) in group-1 (upto 1 year), (5.8\%) in group-5 (above 4 years) and (2.5\%) in group-2 (above 1-2 years) in the present study. Islam et al. (2015) who reported that the incidence of repeat breeding was recorded $1.1 \%$ in young, $2.3 \%$ in adult and $1.1 \%$ in older respectively small ruminant. Zahraddeen et al. (2010) observed that the incidence of reproductive problems accounted in younger animals as compared to adult or old; due to under-development of tissues and organs in young animals but better development with age. This may also be attributed to low level of hormone production requisite for normal body physiological activities at younger age. In addition, high level of reproductive problems may also be linked to low resistance to certain infectious agents at tender age, as similarly reported by Zahraddeen (2006). However, the difference may also occur since low or excess tissue or fat deposition had been implicated in poor reproductive status of animals as reported by (Butswat, 1994). There was no seasonal effect on the incidence of reproductive disorders in goat. The incidence of reproductive disorders was high (34.5\%) in winter season than in summer (32.4\%) and rainy season (31.7\%) (Table 3). We observed higher incidence of reproductive disorders in winter season $(34.5 \%)$ than summer (32.4\%) and rainy season $(31.7 \%)$ in goats in the present study. But Peter et al. (2014) described that highest incidence of reproductive disorders was recorded in rainy season (between April and September) compared with the dry season (between October and March). In another study that was observed by Ahammad et al. (2015) who reported $57.1 \%$ in summer season and $23.4 \%$ in winter season in goats. Islam et al. (2015) reported that more cases were encountered during the month of July to October (rainy season) followed by month of November to February (winter season) than the month of March to June (dry or summer season) which partially agree with Kumar et al. (2013) and disagree with Waziri et al. (2006). Reproductive disorders of goat observed during three seasons by dividing Season-1 (March-June) summer season, Season-2 (July-October) rainy season and Season-3 (November-February) winter season at Upazila Livestock office, sadar, Dinajpur are summarized in Table 4. There was significant difference in the incidence of abortion $(\mathrm{P}<0.05)$ and retained placenta $(\mathrm{P}<0.01)$ in goat in relation on season. But in case of metritis, dystocia, pyometra, anestrus and repeat breeding, there was no significant variation. Among the different reproductive disorders, incidence of abortion was higher in winter season (56.7\%) than rainy season (32.3\%) and summer season (25\%). But the incidence of retained placenta was high (22.2\%) in summer season and low $(2.7 \%)$ in winter season in goat. In case of metritis, higher incidence (32.3\%) was recorded in rainy season. The incidence rate was $22.2 \%$ in summer season in case of dystocia. In pyometra, the incidence was $2.8 \%$ in summer and $0 \%$ in rainy and winter season. The incidence of anestrus were $2.8 \%, 2.6 \%$ and $0 \%$ in summer, winter and rainy season respectively. Overall incidence of reproductive disorders was more or less similar in all season (winter 34.5\%, summer 32.4\% and rainy 31.7\%) (Table 4). Highest incidence of abortion was recorded (56.7\%) in winter season. This result is higher than that of Peter et al. (2014) who reported $0.47 \%$ incidence of abortion in winter season. In another study, Ahammad et al. (2015) reported 12.3\% abortion in summer and 5.4\% abortion in winter season. The incidence of dystocia was higher (22.2\%) in summer season than other season 
(rainy $14.7 \%$ and winter $10.8 \%$ ) in the present study. This result is similar with Ahammad et al. (2015) who reported $21.8 \%$ dystocia in summer season in goat. Bhattacharyya et al. (2015) observed that the highest incidence of dystocia (42.86\%) was recorded in winter season that is slightly higher $(40.4 \%)$ than that observed by Zenebe et al. (2015). Ameen et al. (2013) who reported (13.92\%) dystocia on late wet season in small ruminants. The incidence of metritis was higher (32.3\%) in rainy season in the present study that is similar with Ali et al. (2011) who reported that rainy season was favorable for metritis which was coincided with previous study reported by Markusfeld (1984). The incidence of repeat breeding was higher (14.7\%) in rainy season in the present study. Islam et al. (2015) who reported $0.0 \%$ in summer, $1.1 \%$ in rainy and $3.4 \%$ in winter respectively in small ruminants. Highest incidence of retained placenta was recorded (22.2\%) in summer season in present study. Ameen et al. (2013) who observed that the incidence of retained placenta was higher in early dry season. For the treatment of reproductive disorders in goat, antibiotics drugs were most commonly used. Along with antibiotics, antihistaminic drugs and painkiller, were used to subside the clinical signs. In case of abortion, extra fluid therapy of dextrose, $\mathrm{FeSO}_{4}, \mathrm{CuSO}_{4}$ and $\mathrm{Cucl}_{2}$ and sodium bicarbonate were given to rectify dehydration. Oxytetracycline, ampicillin, procaine penicillin, benzyle penicillin and streptomycin sulphate and amoxycillin and cloxacillin were used as antibiotics in case of retained placenta in goat. Antihistaminic drug and vitamin mineral were also used in case of retained placenta in goat. In case of metritis, oxytetracycline was most commonly used in goat but in case of dystocia, Procaine penicillin, benzyle penicillin and streptomycin sulphate was used. Oxytocin was used as a hormonal drug in case of dystocia. In case of pyometra, antibiotic (procaine penicillin and benzyle penicillin) and antihistaminic drug (pheneramine meleate) were used. Vitamin- mineral (irondextram and cyanocobalamin, sodium bicarbonate, calcium gluconate, magnesium hypophosphate and dextram monohydrate and $\mathrm{CoSO}_{4}, \mathrm{FeSO}_{4}$, thiamin, vit B12 and colin bitartrate) were used in case of anestrus, repeat breeding and infertility. Niclosamide monohydrate was used as anthelmentics drug in case of repeat breeding and infertility in goat (Table 5.1, 5.2; Figure 1). Peters and Ball (1995) reported that dietary deficiencies especially of vitamin $\mathrm{E}$ and selenium are known to cause retained placenta during the dry season. In a metaanalysis, Bourne et al. (2007) suggested that vitamin E supplementation during the dry period reduce the risk of retained placenta and the synthetic forms of vitamin $\mathrm{E}$ were more effective than the natural compound. Most of the reproductive disorders in goat were treated by antihistaminic and pain killer along with the systemic antibiotic drugs. The response to the antibiotics drug were effective (35\%). Only 3\% cases of reproductive disorders were treated by hormonal drug. In this study, it was observed that hormonal drug (oxytocin) was used only in case of dystocia.

Table 1. Overall incidence of reproductive disorders in goat.

\begin{tabular}{lll}
\hline Name of reproductive disorders & Number of affected goats & Incidence (\%) \\
\hline Abortion & 41 & 38.3 \\
Retained placenta & 11 & 10.3 \\
Metritis & 25 & 23.4 \\
Dystocia & 17 & 15.8 \\
Pyometra & 1 & 0.9 \\
Anestrus & 2 & 1.8 \\
Repeat breeding & 10 & 9.3 \\
\hline Total & $\mathbf{1 0 7}$ & $\mathbf{1 0 0}$ \\
\hline
\end{tabular}


Table 2. Incidence of reproductive disorders in goat on the basis of age.

\begin{tabular}{|c|c|c|c|c|c|c|c|c|c|c|c|c|}
\hline \multirow[b]{2}{*}{$\begin{array}{l}\text { Reproductive } \\
\text { disorders }\end{array}$} & \multicolumn{2}{|c|}{$\begin{array}{c}\text { Group-1 } \\
\text { (Upto1 year) }\end{array}$} & \multicolumn{2}{|c|}{$\begin{array}{c}\text { Group-2 } \\
\text { (Above 1-2 years) }\end{array}$} & \multicolumn{2}{|c|}{$\begin{array}{c}\text { Group-3 } \\
\text { (Above 2-3 years) }\end{array}$} & \multicolumn{2}{|c|}{$\begin{array}{c}\text { Group-4 } \\
\text { (Above 3-4 years) }\end{array}$} & \multicolumn{2}{|c|}{$\begin{array}{c}\text { Group-5 } \\
\text { (Above } 4 \text { years) }\end{array}$} & \multirow[t]{2}{*}{$P$ value } & \multirow[t]{2}{*}{$\begin{array}{l}\text { Level of } \\
\text { significance }\end{array}$} \\
\hline & $\begin{array}{l}\text { No. of } \\
\text { animal } \\
\text { affected }\end{array}$ & $\begin{array}{l}\text { Incidence } \\
\%\end{array}$ & $\begin{array}{l}\text { No. of } \\
\text { animal } \\
\text { affected }\end{array}$ & $\begin{array}{l}\text { Incidence } \\
\%\end{array}$ & $\begin{array}{l}\text { No. of } \\
\text { animal } \\
\text { affected }\end{array}$ & $\begin{array}{l}\text { Incidence } \\
\%\end{array}$ & $\begin{array}{l}\text { No. of } \\
\text { animal } \\
\text { affected }\end{array}$ & $\begin{array}{l}\text { Incidence } \\
\%\end{array}$ & $\begin{array}{l}\text { No. of } \\
\text { animal } \\
\text { affected }\end{array}$ & $\begin{array}{l}\text { Incidence } \\
\%\end{array}$ & & \\
\hline Abortion & 11 & 45.8 & 23 & 58.9 & 4 & 17.4 & 1 & 25 & 2 & 11.7 & .003 & $* *$ \\
\hline $\begin{array}{l}\text { Retained } \\
\text { placenta }\end{array}$ & 1 & 4.1 & 5 & 12.8 & 1 & 4.3 & 2 & 50 & 2 & 11.7 & .054 & NS \\
\hline Metritis & 5 & 20.8 & 3 & 7.6 & 8 & 34.7 & 1 & 25 & 8 & 47 & .009 & $* *$ \\
\hline Dystocia & 3 & 12.5 & 5 & 12.8 & 5 & 21.7 & 0 & 0 & 4 & 23.5 & .622 & NS \\
\hline Pyometra & 0 & 0 & 1 & 2.5 & 0 & 0 & 0 & 0 & 0 & 0 & .807 & NS \\
\hline Anestrus & 0 & 0 & 1 & 2.5 & 1 & 4.3 & 0 & 0 & 0 & 0 & .806 & NS \\
\hline Repeat breeding & 4 & 16.6 & 1 & 2.5 & 4 & 17.4 & 0 & 0 & 1 & 5.8 & .182 & NS \\
\hline Total & 24 & 21.6 & 39 & 36.4 & 23 & 21.5 & 4 & 3.6 & 17 & 15.3 & & \\
\hline
\end{tabular}

NS= Not significant $(\mathbf{P}>0.05)$

$* *=$ Significant $(\mathbf{P}<\mathbf{0 . 0 1})$

Table 3. Overall incidence of reproductive disorders in goats on the basis of season.

\begin{tabular}{|c|c|c|}
\hline Season & Number of reproductive disorders & Incidence $(\%)$ \\
\hline Summer & 36 & 32.4 \\
\hline Rainy & 34 & 31.7 \\
\hline Winter & 37 & 34.5 \\
\hline Total & 107 & 100 \\
\hline
\end{tabular}

Table 4. Incidence of individual reproductive disorders in goat on the basis of season.

\begin{tabular}{|c|c|c|c|c|c|c|c|c|}
\hline \multirow[t]{2}{*}{$\begin{array}{l}\text { Reproductive } \\
\text { disorders }\end{array}$} & \multicolumn{2}{|c|}{$\begin{array}{c}\text { Summer season } \\
\text { (March-June) }\end{array}$} & \multicolumn{2}{|c|}{$\begin{array}{l}\text { Rainy season } \\
\text { (July-October) }\end{array}$} & \multicolumn{2}{|c|}{$\begin{array}{c}\text { Winter season } \\
\text { (November-February) }\end{array}$} & \multirow[t]{2}{*}{$P$ value } & \multirow[t]{2}{*}{ Level of significance } \\
\hline & $\begin{array}{l}\text { No. of affected } \\
\text { goats }\end{array}$ & $\begin{array}{l}\text { Incidence rate } \\
(\%)\end{array}$ & $\begin{array}{l}\text { No. of affected } \\
\text { goats }\end{array}$ & $\begin{array}{l}\text { Incidence rate } \\
(\%)\end{array}$ & $\begin{array}{l}\text { No. of affected } \\
\text { goats }\end{array}$ & $\begin{array}{l}\text { Incidence rate } \\
(\%)\end{array}$ & & \\
\hline Abortion & 9 & 25 & 11 & 32.3 & 21 & 56.7 & .013 & $*$ \\
\hline Retained placenta & 8 & 22.2 & 2 & 5.8 & 1 & 2.7 & .009 & $* *$ \\
\hline Metritis & 7 & 19.4 & 11 & 32.3 & 7 & 18.9 & .443 & NS \\
\hline Dystocia & 8 & 22.2 & 5 & 14.7 & 4 & 10.8 & .359 & NS \\
\hline Pyometra & 1 & 2.8 & 0 & 0 & 0 & 0 & .356 & NS \\
\hline Anestrus & 1 & 2.8 & 0 & 0 & 1 & 2.7 & .607 & $\mathrm{NS}$ \\
\hline Repeat breeding & 2 & 5.5 & 5 & 14.7 & 3 & 8.1 & .480 & $\mathrm{NS}$ \\
\hline Total & 36 & 32.4 & 34 & 31.7 & 37 & 34.5 & & \\
\hline
\end{tabular}

$* *=$ Significant $(\mathrm{P}<0.01), *=$ Significant $(\mathrm{P}<0.05), \mathrm{NS}=$ Not significant 
Table 5.1. Current treatment practice and drugs used for reproductive disorders in goat in Dinajpur.

\begin{tabular}{|c|c|c|c|c|c|c|}
\hline \multirow{2}{*}{$\begin{array}{l}\text { Reproductive } \\
\text { disorders } \\
\end{array}$} & \multicolumn{6}{|c|}{ Use of drugs } \\
\hline & Antibiotics & Antihistaminic & Pain killer & Vitamin and mineral & Hormone & Anthelmentics \\
\hline Abortion & $\begin{array}{l}\text { 1. Oxytetracycline } \\
\text { 2. Procaine penicillin, Benzyle } \\
\text { penicillin } \\
\text { 3. Ampicillin }\end{array}$ & $\begin{array}{l}\text { 1. Pheneramine } \\
\text { meleate } \\
\text { 2. Promethazine } \\
\text { hydrochloride } \\
\text { 3. Sulphadimidine }\end{array}$ & 1. Ketoprofen & $\begin{array}{l}\text { 1. Calcium gluconate, Magnesium } \\
\text { chloride and Dextrose } \\
\text { 2. Ferrous sulphate, Copper } \\
\text { sulphate and Copper chloride } \\
\text { 3. Sodium bicabonate }\end{array}$ & - & \\
\hline $\begin{array}{l}\text { Retained } \\
\text { placenta }\end{array}$ & $\begin{array}{l}\text { 1. Oxytetracycline } \\
\text { 2. Ampicillin } \\
\text { 3. Oxytetracycline dihydrate } \\
\text { 4. Procaine penicillin, Benzyle } \\
\text { penicillin, Streptomycin } \\
\text { sulphate } \\
\text { 5. Amoxycillin, cloxacillin }\end{array}$ & $\begin{array}{l}\text { 1. Pheneramine meleate } \\
\text { 2. Promethazine } \\
\text { hydrochloride } \\
\text { 3. Sulphadimidine }\end{array}$ & & $\begin{array}{l}\text { 1. Irondextram, Cyanocobalamin } \\
\text { 2. Sodium bicarbonate } \\
\text { 3. Vitamin- E, Selenium }\end{array}$ & 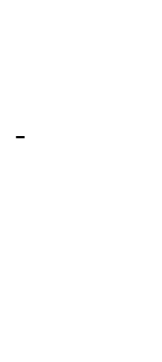 & $\begin{array}{l}\text { Niclosamide } \\
\text { Monohydrate }\end{array}$ \\
\hline Metritis & $\begin{array}{l}\text { 1. Oxytetracycline } \\
\text { 2. Ampicillin } \\
\text { 3. Procaine penicillin, Benzyle } \\
\text { penicillin } \\
\text { 4. Oxytetracycline dihydrate } \\
\text { 5. Amoxycillin, cloxacillin } \\
\text { 6. Procaine penicillin, Benzyle } \\
\text { penicillin, Streptomycin } \\
\text { sulphate } \\
\text { 7. Kanamycin sulphate, colistin } \\
\text { sulphate, neomycin sulphate, } \\
\text { dexamethasone } 21 \text {-sodium } \\
\text { phosphate }\end{array}$ & $\begin{array}{l}\text { 1. Pheneramine meleate } \\
\text { 2. Promethazine } \\
\text { hydrochloride } \\
\text { 3. Sulphadimidine } \\
\text { 4. Chlorpheniramine } \\
\text { Maleate }\end{array}$ & Ketoprofen & $\begin{array}{l}\text { 1. Sodium bicarbonate } \\
\text { 2. Calcium }\end{array}$ & - & \\
\hline
\end{tabular}


Table 5.2. Current treatment practice and drugs used for reproductive disorders in goat in Dinajpur.

\begin{tabular}{|c|c|c|c|c|c|c|}
\hline \multirow{2}{*}{$\begin{array}{l}\text { Reproductive } \\
\text { disorders }\end{array}$} & \multicolumn{6}{|c|}{ Use of drugs } \\
\hline & Antibiotics & Antihistaminic & Pain killer & Vitamin and mineral & Hormone & Anthelmentics \\
\hline Dystocia (After & 1. Procaine penicillin, Benzyle & 1.Pheneramine meleate & 1. Ketoprofen & 1. Sodium bicarbonate & oxytocin (If & \\
\hline Correction of & penicillin, Streptomycin sulphate & 2. Sulphadimidine & 2. Atropine & 2. Calcium & cervix is & \\
\hline \multirow[t]{4}{*}{ Dystocia) } & 2. Oxytetracycline & 3.Promethazine & sulphate & & open) & \\
\hline & 3. Procaine penicillin, Benzyle & hydrochloride & 3. Meloxicam & & & \\
\hline & penicillin & & & & & \\
\hline & 4. Gentamycine & & & & & \\
\hline \multirow[t]{2}{*}{ Pyometra } & 1.Procaine penicillin, Benzyle & 1.Pheneramine meleate & & & & \\
\hline & penicillin & & & & & \\
\hline \multirow[t]{4}{*}{ Anestrus } & & & & 1.Irondextram, cyanocobalamin & & \\
\hline & & & & 2. Sodium bicarbonate, & & \\
\hline & & & & Ammonium bicarbonate, & & \\
\hline & & & & Nuxvomica, Gentain, Ginger & & \\
\hline \multirow[t]{8}{*}{ Repeat breeding } & & & & 1.Irondextram, cyanocobalamin & & Niclosamide \\
\hline & & & & 2. Calcium gluconate, Magnesium & & Monohydrate \\
\hline & & & & hypophosphate, Dextram & & \\
\hline & & & & monohydrate & & \\
\hline & & & & 3. Cobalt sulphate, Ferrous & & \\
\hline & & & & sulphate, Thiamin, monohydrate, & & \\
\hline & & & & VitB $_{12}$, colin & & \\
\hline & & & & 4. Sodium bicarbonate & & \\
\hline
\end{tabular}

1.Irondextram, cyanocobalamin

Sodium bicarbonate,

Ammonium bicarbonate,

Nuxvomica, Gentain, Ginge

.Irondextram, cyanocobalamin

. Calcium gluconate, Magnesium

hypophosphate, Dextram

monohydrate

sulphate, Thiamin, monohydrate,

itB $_{12}$, colin 


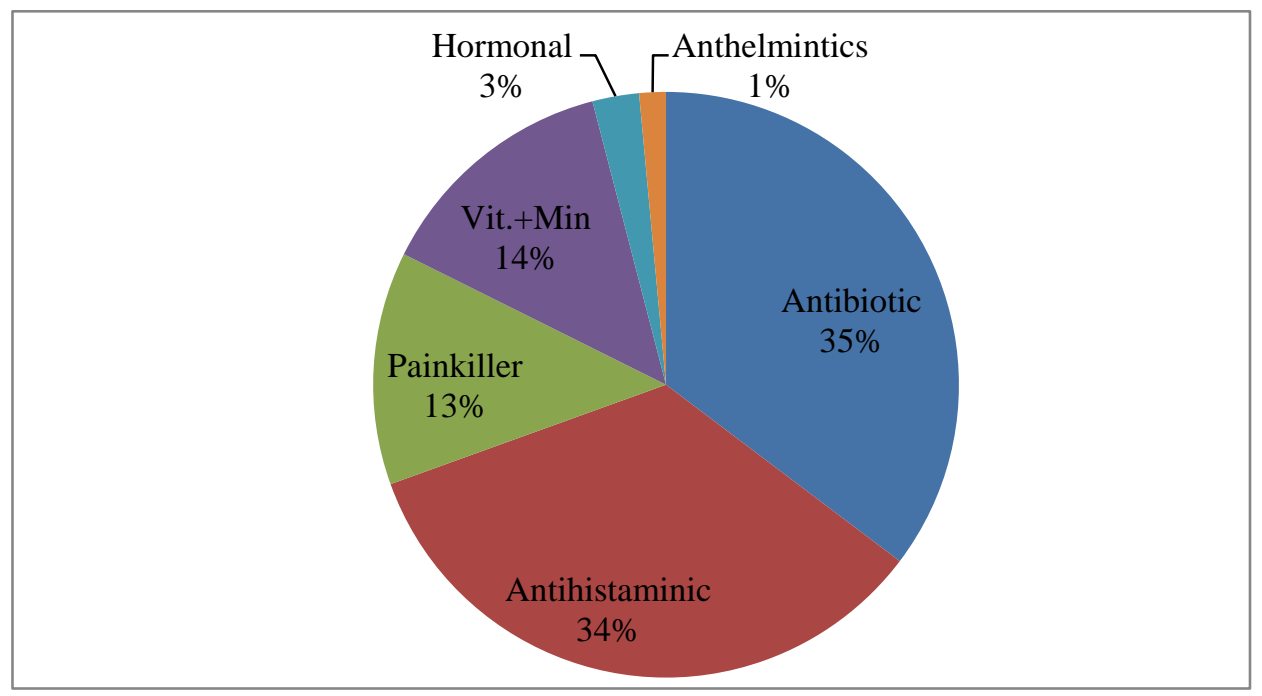

Figure 1. Percentage of drugs used for treatment.

\section{Conclusions}

Overall incidence of reproductive disorders was $12.29 \%$. The major reproductive disorders in goat were recorded abortion $(38.3 \%)$, metritis $(23.4 \%)$, dystocia $(15.8 \%)$, retained placenta $(10.3 \%)$, repeat breeding $(9.3 \%)$, anestrus $(1.8 \%)$ and pyometra $(0.9 \%)$. The reproductive disorders were higher in $2-3$ years age than other groups. Though there is no significant seasonal variation on the incidence of reproductive disorders in goat, therefore, abortion was high in winter season (56.7\%) whereas metritis was high in rainy season (32.3\%). In summer season, the dystocia and retained placenta were high. The most pressing constraint on goat reproduction is abortion, metritis and dystocia. Strategies should be taken to minimize their occurrence.

\section{Acknowledgements}

The authors were greatly acknowledged to Upazila Livestock Office, Sadar, Dinajpur and Department of Medicine, Surgery and Obstetrics, Faculty of Veterinary and Animal Science, Hajee Mohammad Danesh Science and Technology University, Dinajpur for their support.

\section{Conflict of interest}

None to declare.

\section{References}

Ahmed AT, A Balarabe, S Jibril, AA Sidi, RM Jimoh and Gobe, 2017. Incidence and Causes of Dystocia in Small Ruminants in Sokoto Metropolis, Northwestern, Nigeria. Sch. J. of Agric. and Vet. Sci., 4: 114-118.

Ahmed YF, SM Sokkar, HM Desouky and AH Soror, 2008. Abortion due to Toxoplasmosis in small ruminants. Glob. Vet., 2: 337-342.

Ahmed JU, 1993. Incidents of gynaeco-obstetrical disorders in Black Bengal goats. Bang. Agric. Uni. Res. Prog., 7: 499-505.

Ali MH, MKJ Bhuiyanand and MM Alam, 2011. Retrospective epidemiologic study of diseases in ruminants in Khagrachari hill tract district of Bangladesh. J. of Vet. Med., 9: 145-153.

Ameen SA and JA Ajayi, 2013. Studies on influence of seasonality on clinical conditions of small ruminants in Ogbomoso areas of Oyo State. Int. J. of Appl. Agric. and Apicul. Res., 9: 18-27.

Amin MR, SS Hussain and ABMM Islam, 2001. Reproductive peculiarities and litter weight in different genetic groups of Black Bengal does. Asia. -Austral. J. of Ani. Sci., 14: 197-301.

Anusha K, M Praveenraj and VG Naidu, 2016. Incidence of dystocia in small ruminants- A retrospective study. Ind. Vet. J., 93: 40-42.

Bhattacharyya HK, MR Fazili, FA Bhat and BA Buchoo, 2015. Incidence and dystocia of sheep and goats: a study of 70 cases (2004-2011). J. of Adv. Vet. Res., 5: 14-20.

Bourne N, R Laven, DC Wathes, T Martinez and M McGowan, 2007. A meta-analysis of the effects of Vitamin E supplementation on the incidence of retained foetal membranes in dairy cows. Theriogenol., 67: 494-501. 
Butswat IS, 1994. Study on seasonal variation in the reproductive status of sheep and goats in Bauchi. Ph.D. Thesis, Abubakar Tafawa Balewa University, Bauchi, Nigeria. pp. 56.

Devendra C and M Burns, 1983. Goat production in the tropics. Commonwealth Agricultural Bureaux, Franham House, Franham Royal, Slough SL2 3BN, UK.

DLS, 2017. An Annual report. Livestock and poultry development activities. Government of Bangladesh, Dhaka. Available: https:// www.dls.gov.bd

Durrani AZ and N Kamal, 2009. Incidence of genital tract problems in clinical cases of various species of animals. J. of Ani. and Pla. Sci., 19: 160-162.

FAO, 1999. Production Year Book. Food and Agricultural Organization of the United Nations, Rome, Italy, 53: 213-219. Available: https:// www.fao.org.

Fthenaki GC, LS Leontides, GS Amiridis and P Saratsis, 2000. Incidence risk and clinical features of retention of foetal membranes in ewes in 28 flocks in southern Greece. Prev. Vet. Med., 43: 85-90.

Hussain SO and NW Zaid, 2010. Dystocia in goats, causes and treatment. AL-Qad. J. of Vet. Med. Sci., 9: 6368.

Hussain SS, 1999. Sustainable genetic improvment of economic traits of Black Bengal goats through selective and cross breeding. Bangl. Agric. Uni. Res. Prog., 10: 72-80.

Husain SS, 1993. A study on the productive performance and genetic potentials of Black Bengal goats. Ph. D. Dissertation. Department of Animal Breeding and Genetics. Bangladesh Agricultural University, Mymensingh. DLS, 2007. Livestock population in Bangladesh.

Islam MH, MJ Sarder, MS Rahman, MA Haque, MA Islam, SS Jahan and R Khaton, 2015. Retrospective Study of Reproductive Diseases of Small Ruminants in Northern Barind Tract in Bangladesh. Sci., 3: 136-140.

Kamaruddin KM, 2003. Goat farming as a means of poverty alleviation. Proceeding of the BSVER symposium, Goats farming in Bangladesh; Problems and prospects. BAU. Bangladesh society for veterinary education research, BSVER Pub. No. 25 P- 26-34.

Kumar V, SH Talekar, RA Ahmad, DD Mathew and MMS Zama, 2013. Delayed cases of dystocia in small ruminants - etiology and surgical management. Ind. J. of Vet. Sci., 1: 47-54.

Majeed AF and MB Taha, 1989. Dystocia in local goats in Iraq. Sci. Dir., 2: 375-381.

Markusfeld O, 1984. Factors responsible for post parturient metritis in dairy cattle. Vet. Rec., 114: 539.

McDowell RE, 1972. Improvement of livestock production in warm climates 3rd (Ed.) W.H. Freeman and Company, San Fransisco.

Moyo S and FJC Swanepoel, 2010. Multifuncionality of livestock in developing communities in the Role of Livestock in Developing Communities: Enhancing Multifunctionality, edited by Frans Swanepoel, Aldo Stroebel and Siboniso Moyo, Co-published by the Technical Centre for Agricultural and Rural Cooperation (CTA) and University of the Free State.

Peter ID, GD Mshelia, MM Bukar, VA Maina and AA Biu, 2014. Retrospective Studies of Reproductive Disorders of Small Ruminants in Maiduguri, Nigeria. Agric. and Vet. Sci., 6: 55-59.

Peters AR and PJH Ball, 1995. Reproduction in cattle. 2nd Edition, Blackwell Science Ltd, UK.

Phillip PJ, KNM Nayer, SR Nayer, CA Varkey, TA Amma and K Rajankutty, 1985. Caesarean section in goats: A clinical study. Ind. J. of Vet. Surg., 6: 41.

Rahman LYA, AS Al-Janabi and MK Asofi, 2000. Study of some reproduction aspects of the mature local Iraqi goats. The Vet., 10: 47-60.

Rahman A, A Hossain, MU Ahmed and MM Sen, 1977. Studies on some reproductive performance and biometry of the female genital tract of Black Bengal goat. Ind. J. of Ani. Sci., 47: 724-725.

Sattar A and MZ Khan, 1988. Incidence and pathology of ovarian diseases of goats. Pak. Vet. J., 3: 18-21.

Srivastava AK, VK Patil and BK More, 1985. Incidences of various disorders in local, angora crossbreed goats. Ind. Vet. J., 62: 935-939.

Wosu LO and BM Anene, 1990. Incidence and seasonality of reproductive disease conditions in small ruminants in Nsukka area, Nigeria. Beitr. Trop. Landwirtsch. Vet., 28: 18.

Zahradden D, SR Butswat and LS Taimako, 2010. Assessment of reproductive problems in some ruminants under small holder husbandry system in Bauchi, Nigeria. J. of Vet. Sci., 4: 1-8.

Zahraddeen D, 2006. Studies on reproductive performance and milk productivity of goats in Bauchi. An unpublished Ph.D. Thesis, Animal Production Programme, Abubakar Tafawa Balewa University, Bauchi, Nigeria, pp. 210.

Zenebe T, G Kebede, F Gerbi and L Fikirte, 2015. Retrospective Study (2010-2014) of Disease Conditions among Reproductive System of Ruminants at Guto-Gida Veterinary Clinic, East Wollega Zone, Ethiopia. Nat. and Sci., 13: 16-19. 